\title{
Allelopathic EfFects of Rhynchosia capitata On GeRMination ANd Seedling GROWTH OF MUNGBeAN ${ }^{1}$
}

\author{
Efeitos Alelopáticos de Rhynchosia capitata na Germinacão e Crescimento das Mudas de \\ Mungbean
}

\author{
ALI, H.H..$^{*}$, TANVEER, A. ${ }^{2}$, NADEEM, M.A. ${ }^{2}$, JAVAID, M.M. ${ }^{3}$, KASHIF, M.S..$^{2}$, and \\ CHADHAR, A.R. ${ }^{2}$
}

\begin{abstract}
Experiments were conducted to evaluate the allelopathic influence of Rhynchosia capitata on germination and seedling growth of mungbean (Vigna radiate) along with identification of the phytotoxic substances responsible for this activity. Water extracts of root, shoot, leaf, fruit and whole plant were prepared by soaking them in water in a ratio of 1:20 (w/v) for $24 \mathrm{~h}$. All the extracts affected germination and seedling growth of mungbean, but higher inhibition was seen with $R$. capitata leaf water extracts. A linear decrease in the germination characteristics of mungbean was observed with the decrease in the concentration of leaf extract from $5 \%$ to $1 \%$. The soil-incorporated residues $(1-4 \% \mathrm{w} / \mathrm{w})$ of $R$. capitata stimulated the growth of root and hypocotyl at low concentrations, while it inhibited their growth at higher concentrations. Rhynchosia capitata soil-incorporated residues $(4 \% \mathrm{w} / \mathrm{w})$ significantly reduced the seedling vigour index of mungbean in addition to their significant effect on total germination. A significant amount of water-soluble phenolic acids were found in $R$. capitata plant extracts. The content of total phenolic acids was higher in the leaf extract compared to that of the stem, fruit or root extracts. Two phenolic acids including vanillic acid and 4-(hydroxymethyl) benzoic acid were found in $R$. capitata leaf extracts.
\end{abstract}

Keywords: phytotoxic, phenolic, allelopathy, residues, concentration, water extracts

RESUMO - Experimentos foram conduzidos para avaliar a influência alelopática de Rhynchosia capitata na germinação e crescimento das mudas de mungbean (Vigna radiate) juntamente com a identificacão das substâncias fitotóxicas responsáveis por esta atividade. Extratos aquosos da raiz, caule, folha, fruto e planta inteira foram preparados a partir da imersão dos mesmos em água numa razão de 1:20 (w/v) por $24 \mathrm{~h}$. Todos os extratos afetaram a germinação e crescimento das mudas de mungbean, porem a maior inibição se deu com os estratos aquosos foliares de $\boldsymbol{R}$. capitata. Uma diminuição linear nas características de germinação do mungbean foi observada com a diminuição na concentração do extrato foliar de 5\% para $1 \%$. Os resíduos da R.capitata incorporados pelo solo (1-4\%) estimularam o crescimento da raiz e do hipocotil em baixas concentrações, e também inibiram seu crescimento em maiores concentrações. Os residuos de $\boldsymbol{R}$ hyncosia capitata incorporados ao solo $(4 \% \mathrm{w} / \mathrm{w})$ reduziram significativamente o indice de vigor das mudas, tendo também um efeito significativo sobre a germinação total. Uma quantidade significativa de ácidos fenólicos solúveis na água foi encontrada nos extratos das plantas de $\boldsymbol{R}$. capitata. O teor de ácidos fenólicos totais foi mais alto nos extratos foliares do que nos extratos do caule, fruto, ou raiz. Dois ácidos fenólicos, ácido vanílico e acido benzóico (4-hidroximetil), foram encontrados nos extratos foliares de $\boldsymbol{R}$. capitata.

Palavras-chaves: fitotóxico, fenólico, alelopatia, resíduos, concentração, extratos aquosos.

1 Recebido para publicação em 16.7.2012 e aprovado em 17.11.2012.

2 Department of Agronomy, University of Agriculture Faisalabad, 38040, Pakistan; ${ }^{3}$ Department of Agronomy, University College of Agriculture, University of Sargodha, 40100, Pakistan; *Correspondence to <haider3993@gmail.com>. 


\section{INTRODUCTION}

Mountainous regions of the tropics are generally found to support genus Rhyncosia of the Fabaceae family. Rhynchosia capitata an emerging annual summer weed, is indigenous to Pakistan (Jahan et al., 1994), India (Dogra et al., 2009), and Sri Lanka (ILDIS, 2010). It has invaded the cultivated areas of Southern Punjab of Pakistan and is rapidly becoming a problematic weed of farming systems (Ali et al., 2011). It is an annual twinning prostrate plant with many branches spreading all around the rootstock and rooting at every node. Approximately 1-mo-old plant starts flowering and the plant has two-seeded oval-shaped pods (Sharma et al., 1978). Seeds usually require scarification to germinate. Seed dormancy plays a key role in the success of this species by allowing the seeds to persist for long periods in the soil thus escaping the effects of postemergence weed control measures. Its growing season is from May to October with minimum and maximum average temperatures of $29 / 21 \pm 3{ }^{\circ} \mathrm{C}$ and $39 / 29 \pm 3{ }^{\circ} \mathrm{C}$, respectively, and average rainfall of $650 \mathrm{~mm}$ (Ali et al., 2011).

Allelopathic interactions among weeds and crops gained major attention of scientists involved in allelopathic research (Todaria et al., 2005; Singh et al., 2007). De Candolle (1932) reported, for the first time, the injurious effects of root exudates of Canada thistle (Cirsium arvense) on the growth of neighbouring oat plants. Later on, the allelopathic potential of numerous weeds on the crops has been reported (Steenhagen \& Zimdahl, 1979; Singh et al., 1989; Das \& Das, 1996; Jabeen \& Ahmed, 2009). A number of weeds and crop plants have been reported to possess allelopathic potential to affect the growth of other plant species (Rice, 1984). Many plants exhibit allelopathic activity by releasing exudates from living tissues or through decomposition of plant residues which influence other plants in their vicinity (Putnam \& Tang, 1986; Basotra et al., 2005; Singh et al., 2007; Nazir et al., 2007).

Weed species may interfere with the growth of crop plants through allelopathic mechanisms (Putnam \& Tang, 1986). Most of the weed species have inhibitory effects on crops; yet, some weed species also exhibit stimulatory effects on the seed germination, growth and yield of crops (Narwal, 2004). The weeds influence crop plants by releasing allelochemicals from their seeds, decomposing residues, leachates and exudates (Narwal, 2004). Allelopathy may also be one of the several attributes which enable a plant to establish itself in a new ecosystem through invasion followed by succession (Callaway $\&$ Aschehoug, 2000; Ridenour \& Callaway, 2001).

Although many studies on the allelopathic potential of other legume weeds have been published (Kamo et al., 2003; Rashid et al., 2010 ), the allelopathy of $R$. capitata has not yet been evaluated. Rashid et al. (2010) concluded that leaf and root leachates of kudzu (Pueraria lobata) have strong allelopathic potential which could impair growth of lettuce (Lactuca sativa) and radish (Raphanus sativus) seeds (root, shoot length and fresh weight). Kohli et al. (2006) reported that Acacia species affect crop growth by competing for various environmental resources as their litter interferes with the establishment and growth of the adjoining crop plants; in addition, numerous chemical substances, including phenolic compounds, are released in their litter (Seigler, 2003). Allelopathy may be an important aspect in the establishment and competitiveness of common legume weeds.

No research has yet been conducted on the allelopathic effects of $R$. capitata. The main objectives of this research were to study the effects of root, stem, leaf, fruit and whole plant water extracts and soil infested with $R$. capitata on mungbean (Vigna radiate) germination and seedling growth, and to determine water soluble phenolics and total phenolics responsible for the allelopathic activity.

\section{MATERIALS AND METHODS}

\section{Collection of plants and Preparation of water extracts of $R$. capitata}

Rhynchosia capitata plants were collected from a natural population around Layyah, Southern Punjab, Pakistan (30 $57^{\circ} \mathrm{N}, 70^{\circ} 56^{\prime}$ E) in October 2010. The plants were dried at room temperature $\left(30{ }^{\circ} \mathrm{C} \pm 4\right)$ for seven days. Plant material was further dried in an oven at $70{ }^{\circ} \mathrm{C}$ for $48 \mathrm{~h}$. The dried pieces of the $R$. capitata plant (roots, stems, leaves, fruits and whole plant) were separated, weighed, and immersed in tap water at a ratio of 1:20 (w/v) 
at room temperature for $24 \mathrm{~h}$ (Hussain \& Gadoon, 1981). The water extracts of the different parts of $R$. capitata were obtained by filtering through 10- and 60-mesh sieves. Our preliminary trials suggest that $R$. capitata leaves exhibit strong allelopathic affect. Therefore, owing to greater inhibitory activity of leaves, different concentrations (1-4\%) were made by further diluting the leaf extract with distilled water. After 24 hours, the solutions were filtrated and centrifuged at $12.000 \mathrm{rpm}$, and then the extracts were collected. These extracts were individually bottled and tagged. Mungbean seeds were used to test the effect of $R$. capitata on their germination and early seedling growth. The study was carried out in the Laboratory of the Department of Agronomy, University of Agriculture, Faisalabad, Pakistan, in 2010 and 2011.

\section{Lab bioassay}

Effect of water extracts of $R$. capitata plant parts on the germination of mungbean

In this experiment, mungbean seeds were treated with root, stem, leaf, fruit and whole plant extracts and distilled water as a control. Twenty five seeds were placed on filter paper in $9 \mathrm{~cm}$ petri dishes. Before sowing, mungbean seeds were surface-sterilized with $1.5 \%(\mathrm{v} / \mathrm{v})$ sodium hypochlorite solution for $1 \mathrm{~min}$ and washed (three times; $3 \mathrm{~min} /$ wash) in sterile distilled water. In each petri dish, $10 \mathrm{~mL}$ of extract or distilled water was added according to the treatment. To avoid the drying out of seeds throughout the incubation period, the petri dishes were sealed with parafilm. The temperature of the laboratory fluctuated between $32.6 \pm 3.7^{\circ} \mathrm{C}$ during the day and $23.8 \pm 3.2$ during the night. During this period, the petri dishes were observed daily and water or plant extracts were added to each petri dish as needed.

\section{Soil bioassay}

\section{Effect of different concentrations of $R$. capitata-infested soil on the mungbean seedlings}

The decomposition of other plants could release phenolic compounds in the soil, which, in turn, might interfere with the results; sites with no $R$. capitata plants were chosen to collect soil for this experiment. Field soil was dried, crushed, mixed, and placed into $14 \mathrm{~cm}$ diam plastic pots. The soil was a sandy loam with $0.7 \%$ carbon and a $\mathrm{pH}$ of 7.1 . The dried $R$. capitata plants were crushed and mixed with soil of these pots at the rate of 1 , 2,3 and $4 \%(\mathrm{w} / \mathrm{w})$ per pot. After watering, these pots were kept in a greenhouse for 10 days. Then, 10 seeds of mungbean were sown in each pot. Before sowing, mungbean seeds were surface-sterilized with $1.5 \%(\mathrm{v} / \mathrm{v})$ sodium hypochlorite solution for $1 \mathrm{~min}$ and washed (three times; $3 \mathrm{~min} / \mathrm{wash}$ ) in sterile distilled water. The temperature of the laboratory fluctuated between $31.6 \pm 3.7{ }^{\circ} \mathrm{C}$ during the day and $23.8 \pm 3.2$ during the night. After sowing, an adequate water supply to field capacity was ensured. After 21 days, the seedlings were uprooted and washed with water. Seedling fresh weight, length of roots and shoots were measured. Roots and shoots were oven dried at $65{ }^{\circ} \mathrm{C}$ for $72 \mathrm{~h}$ until a constant weight was obtained to measure dry weight of root, shoot and seedlings.

\section{Determination of total soluble phenolics in $R$. capitata}

Total soluble phenolics were determined as described by Randhir \& Shetty (2005) and were expressed as gallic acid equivalents.

\section{Detection of phytotoxins in water $R$. capitata extracts}

Due to their greater suppression potential, water extracts of $R$. capitata leaf were chemically analyzed on a Shimadzu HPLC system (Model SCL-10A, Tokyo, Japan) for identification and quantification of their suspected phytotoxins. The conditions of separation are listed in Table 4.

The peaks were detected by a UV detector. Standards of suspected phytotoxins (Aldrich, St Louis, USA) were run similarly for identification and quantification. Standards of phenolics were prepared at different concentrations. Vanillic acid and 4-(hydroxymethyl) benzoic acid were identified by their retention time with authentic standards. Concentration of each isolated compound was determined by the following equation: 
Concentration $(\mathrm{ppm})=\frac{\text { Area of the sample }}{\text { Area of the standard }} \times$ Concentration of the st

\section{Statistical analysis}

Each experiment was staged in a completely randomized design (CRD) with four replicates. All experiments were repeated. The data from the repeated experiments were combined because there was no time-bytreatment interaction. The Germination/ Emergence Index (GI/EI) was calculated as described by the Association of Official Seed Analysts (AOSA, 1990) by using the following formula:

$\mathrm{GI}=\frac{\text { No. of germinated seeds }}{\text { Days of first count }}+------+\frac{\text { No. of germinated seeds }}{\text { Days of final count }}$

Time taken to $50 \%$ Germination/ Emergence of seedlings $\left(T_{50}\right)$ was calculated according to the following formula of Coolbear et al. (1984),

$$
T_{50}=t i+\frac{\left(N / 2-n_{j}\right)\left(t_{j}-t_{i}\right)}{n_{j}-n_{i}}
$$

where $N$ is the final number of germinated seeds, and $n_{i}$ and $n_{j}$ are the cumulative number of seeds germinated by adjacent counts at times $t_{i}$ and $t_{j}$, respectively, when $n_{i}<N / 2<n_{j}$

Mean Germination/Emergence time was calculated according to the equation of Ellis \& Roberts (1981):

$$
M G T / M E T=\Sigma\left(D_{n}\right) / \Sigma n
$$

where $n$ is the number of germinated seeds or emerged seedlings on day $D$ and $D$ is the total number of days counted from the beginning of germination.

The Seedling Vigor Index (SVI) was calculated according to the following formula of Abdul-Baki \& Anderson 1973):

SVI $=$ Germination /Emergence $\% \times$ Radical length $(\mathrm{cm})$

Data were analyzed statistically by Fisher's ANOVA function of the MSTAT statistical computer package, and LSD at $5 \%$ probability was used to compare the treatment means (Steel et al., 1997).

\section{RESULTS AND DISCUSSION}

Allelopathic effects of different plant parts of $R$. capitata on germination percentage of mungbean are shown in Figure 1. The results showed that water extracts of various plant parts of $R$. capitata reduced the germination percentage of mungbean seeds compared with the distilled water (control). The minimum germination $(62 \%)$ was observed in leaf extracts of $R$. capitata, while the maximum germination was found in the control treatment $(97 \%)$. Moreover, water extracts of the root, stem, leaf whole plant and fruit of $R$. capitata significantly affected the time taken to $50 \%$ germination $\left(\mathrm{T}_{50}\right)$, mean germination time (MGT) and Germination Index (GI) of mungbean as compared to the control treatment (Table 1). The mungbean seeds took significantly more time to reach $\mathrm{T}_{50}$ and complete germination with root, stem, leaves, whole plant and fruit extracts of $R$. capitata compared with those in the distilled water. The seeds soaked in the root and fruit extract took less time to reach $\mathrm{T}_{50}$ and for mean germination than those soaked in the stem, leaves and whole plant extracts of $R$. capitata. Maximum mean germination time (5.31 days) was recorded in case of leaf extract followed by whole plant extract (4.65 days). The root, stem, leaves, whole plant

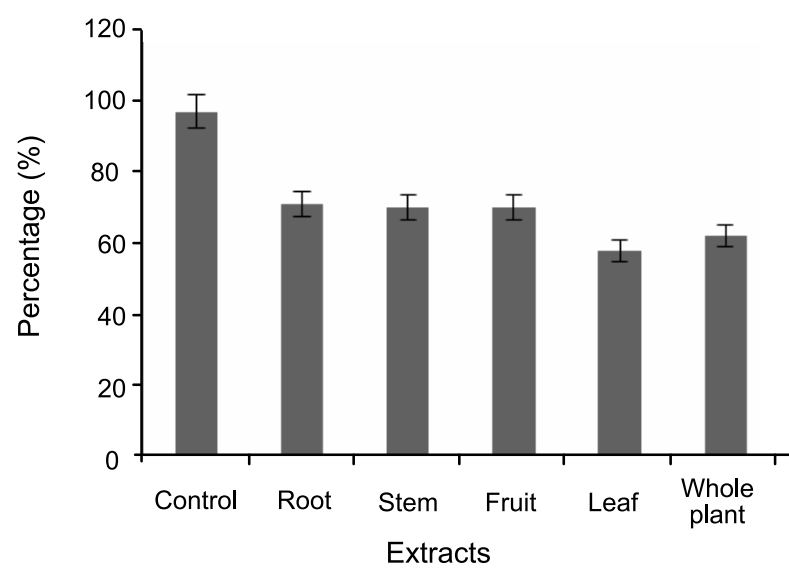

Figure 1 - Effect of $R$. capitata extracts on the germination of mungbean. 
Table 1 - Effect of $R$. capitata extracts on the germination traits of mungbean

\begin{tabular}{|l|c|c|c|}
\hline \multicolumn{1}{|c|}{ Treatment } & $\mathrm{T}_{50}(\mathrm{~d})$ & MGT (d) & GI \\
\hline Control & $0.69 \mathrm{e}$ & 2.17 & $18.41 \mathrm{a}$ \\
\hline Root Extract & $3.48 \mathrm{~d}$ & $3.91 \mathrm{~d}$ & $11.08 \mathrm{~b}$ \\
\hline Stem Extract & $4.32 \mathrm{c}$ & $4.55 \mathrm{c}$ & $9.85 \mathrm{c}$ \\
\hline Fruit Extract & $3.36 \mathrm{~d}$ & $3.88 \mathrm{~d}$ & $11.25 \mathrm{~b}$ \\
\hline Leaf Extract & $6.61 \mathrm{a}$ & $5.31 \mathrm{a}$ & $6.99 \mathrm{e}$ \\
\hline Whole Plant Extract & $5.28 \mathrm{~b}$ & $4.65 \mathrm{~b}$ & $8.08 \mathrm{~d}$ \\
\hline LSD (0.05) & 0.45 & 0.089 & 1.004 \\
\hline
\end{tabular}

Means followed by the same letter in a column did not differ significantly according to the LSD test $(p<0.05)$

T50: Time needed for 50\% germination; MGT: Mean Germination Time; GI: Germination Index; LSD: Least Significance Difference.

and fruit extracts significantly decreased the germination index of mungbean compared with the distilled water, with the maximum reduction noted in the leaf extract.

These results suggest that the phytotoxicity of $R$. capitata leaf, stem, fruit, whole plant and root extracts may be due to restriction of water uptake and, hence, inhibition of seed germination. Maximum total phenolics were detected in the leaf extract as compared to all other extracts (Figure 4) which showed that inhibition of germination is due to the presence of more phenolics in the leaf extract. Interruption in water uptake caused a decrease in seed protease activity, which played a key role in protein hydrolysis during germination and, to a large extent, was related to imbibition and water uptake of seeds (Rice, 1984). The results are supported by the findings of Babar et al. (2009), who stated that chickpea seeds soaked in root extract of Asphodelus tenuifolius took more time for germination. Similarly, Tawaha \& Turk (2003) also observed an inhibitory effect of allelochemicals on water imbibition by wild barley (Hordeum leporinum) in a study on the allelopathic effects of black mustard (Brassica nigra).

Figure 2 represents the effect of different concentrations of leaf extracts on the germination of mungbean seeds. The results showed that there was a gradual decrease in the germination percentage of mungbean seeds with the increasing concentration of the leaf extract of $R$. capitata. The 5\% leaf extract of $R$. capitata caused the maximum reduction in the germination percentage compared to other concentrations as well as the distilled water treatment. The data shown in Table 2 demonstrate the effect of applying different concentrations of $R$. capitata leaf extracts on the different germination traits of mungbean. The data revealed that all the concentrations of leaf extract increased the time taken to reach $50 \%$ germination compared with the distilled water, but the most significant increase was recorded with the 5\% leaf extract. The $1 \%$ leaf extract of $R$. capitata increased the mean germination time but the marked increase in the mean germination time of mungbean seeds was recorded at higher concentrations $(2 \%-5 \%)$ of $R$. capitata, compared with the control. The Germination

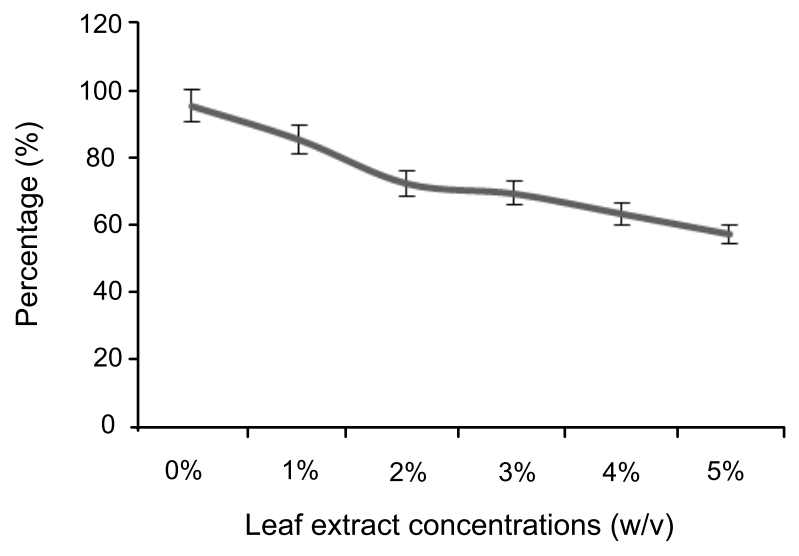

Figure 2 - Effect of different concentrations of $R$. capitata leaf extracts on the germination percentage of mungbean.

Table 2 - Effect of different concentrations of $R$. capitata leaf extracts on the germination traits of mungbean

\begin{tabular}{|l|c|c|c|}
\hline \multicolumn{1}{|c|}{ Treatment } & $\mathrm{T}_{50}(\mathrm{~d})$ & MGT $(\mathrm{d})$ & GI \\
\hline Control & $0.68 \mathrm{e}$ & $2.17 \mathrm{~d}$ & $18.16 \mathrm{a}$ \\
\hline $1 \%$ Extract & $3.14 \mathrm{~d}$ & $4.56 \mathrm{bc}$ & $11.87 \mathrm{~b}$ \\
\hline $2 \%$ Extract & $4.12 \mathrm{c}$ & $4.54 \mathrm{c}$ & $10.22 \mathrm{c}$ \\
\hline $3 \%$ Extract & $4.43 \mathrm{c}$ & $4.57 \mathrm{bc}$ & $9.57 \mathrm{c}$ \\
\hline $4 \%$ Extract & $5.10 \mathrm{~b}$ & $4.67 \mathrm{~b}$ & $8.16 \mathrm{~d}$ \\
\hline $5 \%$ Extract & $6.61 \mathrm{a}$ & $5.31 \mathrm{a}$ & $6.99 \mathrm{e}$ \\
\hline LSD $(0.05)$ & 0.4487 & 0.1016 & 0.9005 \\
\hline
\end{tabular}

Means followed by the same letter in a column did not differ significantly according to the LSD test $(\mathrm{p}<0.05)$.

T50: Time needed for $50 \%$ germination; MGT: Mean Germination Time; GI: Germination Index; LSD: Least Significance Difference. 
Index of mungbean seeds significantly decreased with the increasing concentrations of leaf extract, but it was statistically similar to the $2 \%$ and $3 \%$ leaf extracts.

The results of our studies showed that leaves of $R$. capitata enjoyed significantly greater allelopathic effect as compared to other parts of the plant. The greater number of growth inhibitors detected in the leaves explains the stronger inhibitory activity. These results were supported by the findings of Kadioglue et al. (2005). They reported inhibition in the germination rate and final germination of lentil (Lens culinaris), chickpea (Cicer arietinum), and wheat (Triticum aestivum) with different plant part extracts of several broad and narrow leaf weeds. Our findings were also in line with those of Tanveer et al. (2010), who concluded that leaf extract had a greater inhibitory effect than the other extracts while investigating the allelopathic effect of root, stem, leaf, and fruit water extracts and infested soil of Euphorbia helioscopia on the seed germination and seedling growth of wheat, chickpea, and lentil. Similarly, Dongre \& Singh (2007) also concluded that the leaf leachates of Amaranthus viridis, Parthenium hysteroporus and Polygonum plebeium significantly inhibited the growth of Triticum aestivum.

The effects of different concentrations of $R$. capitata soil-incorporated residues on the emergence percentage of mungbean seedlings are shown in Figure 3 . The results showed that mungbean seedling emergence percentage was significantly higher $(95 \%)$ in $R$. capitata free soil followed by that the $1 \%$ soil residues of $R$. capitata (55\%). The significantly minimum emergence percentage $(10 \%)$ of mungbean was recorded in $4 \%$ soil residues of $R$. capitata. The data presented in Table 3 showed the impact of different concentrations of soil residues of $R$. capitata on the emergence characteristics of mungbean. Mungbean seedlings took minimum time ( 0.48 days) to complete $50 \%$ emergence in the control treatment, whereas maximum time to complete $50 \%$ emergence was recorded in $4 \%$ soil residues of $R$. capitata, in which the seeds took 12.75 days. The Emergence Index was significantly higher (3.85) in the control treatment followed by the $1 \%$ and $3 \%$ soil residues of $R$. capitata $(0.88$ and 0.49 ,

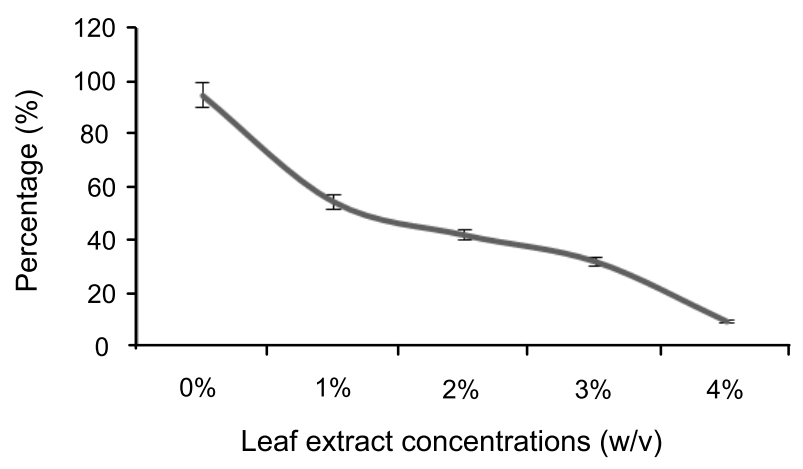

Figure 3 - Effect of $R$. capitata -infested soil on the seedling emergence percentage of mungbean.

Table 3 - Effect of R. capitata - infested soil on the germination indices and seedling characteristics of mungbean

\begin{tabular}{|c|c|c|c|c|c|c|c|c|c|}
\hline \multirow[t]{2}{*}{ Treatment } & \multirow[t]{2}{*}{$\begin{array}{l}\mathrm{T}_{50} \\
\text { (d) }\end{array}$} & \multirow[t]{2}{*}{ EI } & \multirow[t]{2}{*}{$\begin{array}{l}\text { MET } \\
\text { (d) }\end{array}$} & $\begin{array}{c}\text { Root } \\
\text { Length } \\
(\mathrm{mm})\end{array}$ & $\begin{array}{c}\text { Shoot } \\
\text { length }(\mathrm{mm})\end{array}$ & $\begin{array}{c}\text { Root dry } \\
\text { weight }(\mathrm{mg})\end{array}$ & $\begin{array}{c}\text { Shoot dry } \\
\text { weight }(\mathrm{mg})\end{array}$ & $\begin{array}{l}\text { Seedling dry } \\
\text { weight }(\mathrm{mg})\end{array}$ & \multirow[t]{2}{*}{ SVI } \\
\hline & & & & \multicolumn{2}{|c|}{$(\mathrm{mm})$} & \multicolumn{3}{|c|}{$(\mathrm{mg})$} & \\
\hline Control & $0.48 \mathrm{~d}$ & $3.85 \mathrm{a}$ & $3.51 \mathrm{~d}$ & $64.00 \mathrm{a}$ & $45.25 \mathrm{a}$ & $45.25 \mathrm{a}$ & $122.50 \mathrm{a}$ & $278.25 \mathrm{a}$ & $609.00 \mathrm{a}$ \\
\hline $1 \%$ Residue & $5.20 \mathrm{c}$ & $0.88 \mathrm{~b}$ & $8.37 \mathrm{c}$ & $49.50 \mathrm{~b}$ & $26.50 \mathrm{~b}$ & $26.50 \mathrm{~b}$ & $94.00 \mathrm{~b}$ & $235.00 \mathrm{~b}$ & $272.50 \mathrm{~b}$ \\
\hline $2 \%$ Residue & $6.50 \mathrm{c}$ & $0.49 \mathrm{c}$ & $9.48 \mathrm{~b}$ & $43.75 \mathrm{~b}$ & $18.50 \mathrm{c}$ & $18.50 \mathrm{c}$ & $83.25 \mathrm{c}$ & $211.00 \mathrm{c}$ & $186.50 \mathrm{c}$ \\
\hline 3\% Residue & $8.50 \mathrm{~b}$ & $0.34 \mathrm{~cd}$ & $10.75 \mathrm{a}$ & $28.25 \mathrm{c}$ & $14.00 \mathrm{~cd}$ & $14.00 \mathrm{~cd}$ & $64.25 \mathrm{~d}$ & $167.25 \mathrm{~d}$ & $92.00 \mathrm{~d}$ \\
\hline 4\% Residue & $12.75 \mathrm{a}$ & $0.11 \mathrm{~d}$ & $10.91 \mathrm{a}$ & $20.25 \mathrm{c}$ & $9.25 \mathrm{~d}$ & $9.25 \mathrm{~d}$ & $32.50 \mathrm{e}$ & $89.25 \mathrm{e}$ & $21.75 \mathrm{~d}$ \\
\hline 5\% Residue & NG & NG & NG & NG & NG & NG & NG & NG & NG \\
\hline $\operatorname{LSD}(0.05)$ & 1.6033 & 0.2991 & 1.0085 & 9.2027 & 6.2929 & 6.2929 & 8.5745 & 13.060 & 72.845 \\
\hline
\end{tabular}

Means followed by the same letter in a column did not differ significantly according to the LSD test $(\mathrm{p}<0.05)$.

SVI: Seedling Vigor Index, T50: Time needed for 50\% germination; MGT: Mean Germination Time; GI: Germination Index; NG: Nongerminated; LSD: Least Significance Difference. 
respectively). Minimum mean emergence time (MET) (3.51 days) was observed in the control treatment while the seeds took significantly maximum MET (10.91 days) in the $4 \%$ soil residues of $R$. capitata.

Rhynchosia capitata infested soil significantly inhibited the root length, shoot length, shoot dry weight, seedling dry weight and seedling vigour index of mungbean (Table 3). In all cases, the largest seedlings in terms of root and shoot length were found in the control treatment that had no $R$. capitata residues. The results of this experiment indicate that the $4 \%$ soil-incorporated residues of $R$. capitata caused maximum reduction in root and shoot length as well as seedling vigour index of mungbean seedlings. Similarly,

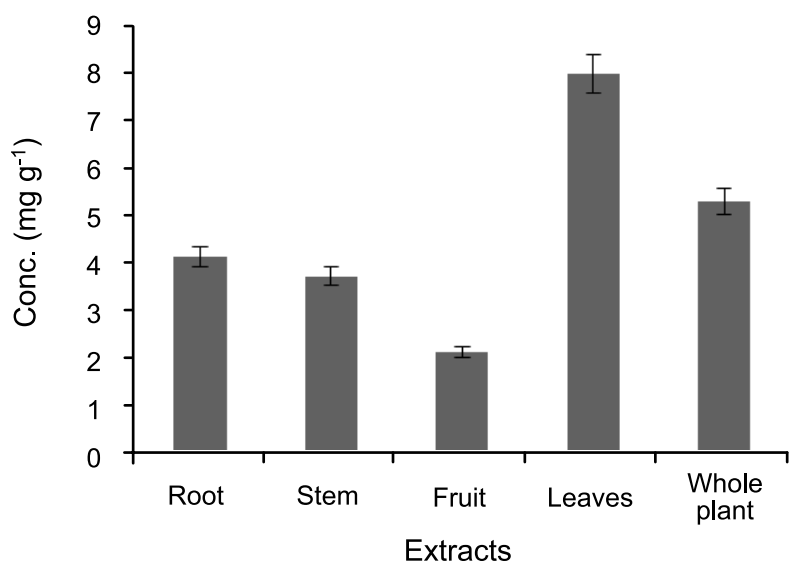

Figure 4 - Determination of total water soluble phenolics in different plant parts of $R$. capitata. minimum dry weights of root, shoots and seedlings were also observed in the $4 \%$ soil residues as compared to other concentrations of $R$. capitata soil residues as well as the control treatment.

The results are supported by the findings of Rashid et al. (2010), who reported impaired growth of lettuce (Lactuca sativa) and radish (Raphanus sativus) seeds (root and shoot length and fresh weight) by the allelopathic potential of leaf and root leachates of kudzu (Pueraria lobata). Tanveer et al. (2008) also reported that minimum GI and germination percentage of rice seeds were observed when such seeds were treated with leaf leachates of Common Cocklebur (Xanthium strumarium). Similarly, Stavrianakou et al. (2004) also documented the inhibition of germination, germination index and increase in germination time of chickpea and lentil with the extract of different weeds.

Two phenolic acids (vanillic acid and 4-(hydroxymethyl) benzoic acid) were found in the $R$. capitata extract, and vanillic acid was the most prominent (Table 4). Phenolic acids have been found in a wide range of plants and soils and are often mentioned as putative allelochemicals (Inderjirt, 1996; Inderjit \& Nishimura, 1999). It has also been demonstrated that mixtures of phenolic acids have additive inhibitory action and/or synergistic inhibitory action (Einhellig, 1999).

The results obtained in this study show that the water extracts of $R$. capitata

Table 4 - HPLC conditions for determination of phytotoxins in leaf water extract of $R$. capitata

\begin{tabular}{|c|c|}
\hline Parameter & Characteristic \\
\hline Column dimensions & $25 \mathrm{~cm}$ length $\times 4.6 \mathrm{~mm}$ diameter, particle size of $5 \mu \mathrm{m}$ \\
\hline Diatomite & Supleco wax 10 \\
\hline Attenuation & $0.01 \mathrm{ppm}$ \\
\hline Rate of recorder & $10 \mathrm{~mm} \mathrm{~min}^{-1}$ \\
\hline Detector & SPD-10A vp-detector \\
\hline Detection & $\mathrm{UV}, 280 \mathrm{~nm}$ \\
\hline Flow rate & $0.25 \mathrm{~mL} \mathrm{~min}^{-1}$ \\
\hline Volume injection sample & $50 \mu \mathrm{L}$ \\
\hline Type of Column & Shim-pack CLC-Octadecyl Silicate (ODS) (C-18) \\
\hline Mobile phase & Isocrartic; $100 \%$ methanol \\
\hline Temperature & $25^{\circ} \mathrm{C}$ \\
\hline
\end{tabular}


possess allelochemicals that suppressed the germination and seedling growth of mungbean. The presence of a considerable amount of phenolic acids suggests that it is essential to monitor this weed at the emergence stage so that its inhibitory effects on the crop may be avoided. These results were obtained under laboratory conditions. The evaluation of the allelochemicals and their isolation, identification, release, and movement under field conditions are important guidelines for future research.

\section{LITERATURE CITED}

ABDUL-BAKI, B. A. A.; ANDERSON, J. D. Relationship between decarboxylation of glutamic acid and vigour in soybean seed. Crop Sci., v. 13, n. 2, p. 222-226, 1973

ALI, H. H. et al. Methods to break seed dormancy of Rhynchosia capitata, a summer annual weed. Chil. J. Agric. Res., v. 71, n. 3, p. 483-487, 2011.

ASSOCIATION OF OFFICIAL SEED ANALYSIS - ASOA. Rules for testing seeds. J. Seed Technol., v. 12, n. 3, p. $1-112,1990$.

BABAR, B. H. et al. Allelopathic potential of wild onion (Asphodelus tenuifolius) on the germination and seedling growth of chickpea (Cicer arietinum). Weed Biol. Manag., v. 9 , n. 2, p. 146-151, 2009

BASOTRA, R.; CHAUHAN, S.; TODARIA, N. P. Allelopathic effects of medicinal plants on food crops in Garhwal Himalaya. J. Sust. Agric., v. 26, n. 3, p. 43-56, 2005.

CALLAWAY, R. M.; ASCHEHOUG, E. T. Invasive plants versus their new and old neighbors: a mechanism for exotic invasion. Science, v. 290, n. 1, p. 521-523, 2000

COOLBEAR, P.; FRANCIS, A.; GRIERSON, D. The effect of low temperature pre-sowing treatment on the germination performance and membrane integrity of artificially aged tomato seeds. J. Exper. Bot., v. 35, n. 11, p. 1609-1617, 1984.

DAS, N. R.; DAS, A. K. Allelopathic effects of rainfed paira linseed (Linum usitatimum) on Vicia and Melilotus weeds in West Bengal. World Weeds, v. 5, n. 1, p. 21-25, 1996.

DE CANDOLLE, M. A. P. Physiologie vegetale. Paris: Bechet Jeune, 1932. p. 1474-1475. Tome III.

DOGRA, K. S. et al. Comparison of understorey vegetation in exotic and indigenous tree plantations in Shivalik Hills of N. W. Indian Himalayas (Himachal Pradesh). J. Ecol. Nat. Environ., v. 1, n. 5, p. 130-136, 2009.

Planta Daninha, Viçosa-MG, v. 31, n. 3, p. 501-509, 2013
DONGRE, P. N.; SINGH, A. K. Inhibition effects of weeds on growth of wheat seedlings. Allelopathy J., v. 20, n. 2 , p. 387-394, 2007.

EINHELLIG, F. A. An integrated view of allelochemicals amid multiple stresses. In: INDERJT, I.; DAKSHINI, K. M. M.; FOY, C. L. (Ed.). Principles and practices in plant ecology: allelochemical interactions Boca Raton: CRC Press, 1999. p. 479-494.

ELLIS, R. A.; ROBERTS, E. H. The quantification of aging and survival in orthodox seeds. Seed Sci. Technol., v. 9, n. 2, p. 373-409, 1981.

HUSSAIN, F.; GADOON, M. A. Allelopathic effects of Sorghum vulgare Pers. Oecologia, v. 51, n. 2, p. 284-288, 1981.

ILDIS: online [Internet]. International Legume Database and Information Service. [cited 2010 January11]. Available from: $<$ http://www.ildis.org/LegumeWeb>, 2010.

INDERJIRT, I. Plant phenolies in Allelopathy. Bot. Rev., v. 62 , n. 2 , p. $186-202,1996$

INDERJT, I.; NISHIMURA, H. Plant phenolics and terpenoid:transformation, degradation, and potential of allelopathic interactions. In: INDERJT, I.; DAKSHINI, K. M. M.; FOY, C. L. (Ed.). Principles and practices in plant ecology: allelochemical interactions. Boca Raton: CRC Press, 1999. p. $255-266$.

JABEEN, N.; AHMED, M. Possible allelopathic effects of three different weeds on germination and growth of maize (Zea mays) cultivars. Pak. J. Bot., v. 41, n. 4, p. 1677-1683, 2009.

JAHAN, B.; VAHIDY, A. A.; ALI, S. I. Chromosome numbers in some taxa of Fabaceae mostly native to Pakistan. Ann. Missouri Bot. Garden., v. 81, n. 4, p. 792-799, 1994.

KADIOGLUE, I.; YANAR Y.; ASAV. U. Allelopathic effects of weed leachates against seed germinatio $\mathrm{n}$ of some plants. J. Environ. Biol., v. 26, n. 2, p. 169-173, 2005.

KOHLI R. K.; BATISH, D. R.; SINGH, P. H. Allelopathic interaction in agroecosystems. In: REIGOSA, M. J., PEDROL, N.; GONZÁLEZ, L. (Ed.). Allelopathy: a physiological process with ecological implications. Dordrecht: Springer, 2006. p. 465-493.

KAMO, T.; HIRADATE, S.; FUJI, Y. First isolation of natural cyanamide sa possible allelochemical from hairy vetch Vicia vilosa . J. Chem. Ecol., v. 29, n. 2, p. 275-283, 2003.

NAZIR, T.; UNIYAL, A. K.; TODARIA, N. P. Allelopathic behavior of three medicinal plant species on traditional agriculture crops of Garhwal Himalaya, India. Agrofor. Syst., v. 69, n. 3 , p. $183-187,2007$. 
NARWAL, S. S. Allelopathy in crop production. Jodhapur: Scientific Publishers, 2004.

PUTNAM, A. R.; TANG, C. S. The science of allelopathy. New York: John Wiley \& Sons, 1986. 317 p.

RANDHIR, R.; SHETTY, K. Developmental stimulation of total phenolics and related antioxidant activity in light and dark germinated maize by natural elicitors. Process

Biochem., v. 40, n. 5, p. 1721-1732, 2005

RASHID, Md. H. et al. The Allelopathic Potential of Kudzu (Pueraria montana). Weed Sci., v. 58, n. 1, p. 47-55, 2010.

RICE, E. L. Allelopathy. 2.ed. Boca Raton: Academic Press, 1984. 424 p.

RIDENOUR, W. M.; CALLAWAY, R. M. The relative importance of allelopathy in interference: the effects of invasive weed on native bunchgrass. Oecologica, v. 126, n. 3 , p. 444-450, 2001.

SEIGLER, D. S. Phytochemistry of Acacia - sensu lato. Biochem. Syst. Ecol., v. 31, n. 8, p. 845-873, 2003.

SHARMA, N. K.; SHARMA, M. M.; SEN, D. N. Seed Perpetuation in Rhynchosia capitata DC. Biol. Plant., v. 20, n. 3, p. 225-228, 1978.

SINGH, C. M.; ANGIRAS N. N.; SINGH, S. D. Allelopathic effects of root exudates from obnoxious weed Parthenium hysterophorus L. Indian J. Weed Sci., v. 20, n. 1, p. 18-22, 1989.
SINGH, B.; UNIYAL, A. K.; TODARIA, N. P. Studies on allelopathic influence of Zanthoxylum armatum D.C. on important field crops seeking its sustainable domestication in existing agroforestry systems of Garhwal Himalaya, India J. Sust. Agric., v. 30, n. 3, p. 87-95, 2007.

STAVRIANAKOU, S. et al. Allelopathic effect of watersoluble leaf epicuticular material from Dittrichia viscosa on seed germination of crops and weed. Allelopathy J., v. 14, n. 1, p. $35-41,2004$.

STEEL, R. G. D.; TORRIE, J. H.; DICKEY, D. A. Principles and procedures of statistics. A biometrical approach 3.ed. Singapore: McGraw Hill Book, 1997. p. 172-177.

STEENHAGEN, D. A.; ZIMDAHL. R. H. Allelopathy of leafy spurge (Euphorbia esula). Weed Sci., v. 27, n. 1, p. 1-3, 1979.

TAWAHA, A. M.; TURK, M. A. Allelopathic Effects of Black Mustard (Brassica nigra) on Germination and Growth of Wild Barley (Hordeum spontaneum). J. Agron. Crop Sci., v. 189, n. 5, p. 298-303, 2003.

TANVEER, A. et al. Allelopathic potential of Euphorbia helioscopia L. against wheat (Triticum aestivum L.), chickpea (Cicer arietinum L.) and lentil (Lens culinaris Medic.). Turk. J. Agric. For., v. 34, n. 1, p. 75-81, 2010

TODARIA, N. P.; SINGH B.; DHANAI, C. S. Allelopathic effects of tree extract, on germination and seedling growth of field crops. Allelopathy J., v. 15, n. 2, p. 285-294, 2005. 